Teka Kom. Politol. Stos. Międzynar. - OL PAN, 2016, 11/1, 125-137

\title{
TAIWAN'S SECESSION AGAINST TWO HOSTS: THE XI-MA SUMMIT AND ITS IMPLICATIONS FOR FUTURE CROSS-STRAIT RELATIONS*
}

\author{
Chunjuan Nancy Wei ${ }^{1}$ \\ University of Bridgeport, Connecticut \\ Department of International Political Economy \& Diplomacy \\ East Asia \& Pacific Rim Studies \\ e-mail: chunjuaw@bridgeport.edu
}

\begin{abstract}
Taiwan commands the world's attention because of the geopolitics that enables the island to play a role bigger than its size. Democracy and secessionist movements that came hand in hand since the 1980s in Taiwan have further complicated matters, leading to a level of chaos and decline of competitiveness in Taiwan's once-vibrant economy. Cross-Strait relations have greatly improved but the situation remains an "unstable peace," to use the terminology of the Lund Curve, because of the existence of an independence-leaning coalition and its constituents. Although considerable trade and tourism have linked the two sides and direct negotiations have produced 23 agreements, political and security ties remain sensitive. China's chief goal remains national reunification, while the majority of Taiwanese voters tend to favor the status quo. This paper discusses a unique two-host phenomenon in Taiwan's secessionist movement, nonexistent in other similar movements. It traces President Ma Ying-jeou's approach to cross-Strait relations, explaining reasons that led to Ma's unprecedented summit with his counterpart Xi Jinping. Without understanding the concept of the two hosts, it would be impossible to make sense of the extraordinary reconciliation, epitomized in the $\mathrm{Xi}$-Ma handshake.
\end{abstract}

Keywords: Taiwan's Secessionist Movement against Two Hosts; Xi-Ma Summit; Unstable Peace; Cross-Strait Security; Lund's Curve; Taiwan's 2016 Election

* Part of this research was conducted while the author was a Fulbright Scholar in Taiwan and the Mainland China. The author wishes to thank the Fulbright Foundation for supporting her research. The views expressed here are solely those of the author and do not represent in any way the views of her employer the University of Bridgeport or the awarding institution.

1 Dr. Chunjuan Nancy Wei, a Fulbright Scholar in Taiwan and Mainland China (2014-15), teaches in the M.A. East Asian \& Pacific Rim Studies and the B.A. International Political Economy \& Diplomacy programs at the University of Bridgeport in Connecticut, USA. She has published on the South China Sea disputes, U.S.-China relations, East Asian political economy, and cross-Taiwan Strait politics in such journals as the Harvard Asia Quarterly, Yale Journal of International Affairs, the Southeast Review of Asian Studies, the Eurasia Review, and The Diplomat. 


\section{INTRODUCTION}

Taiwan commands the world's attention because of the geopolitics that enables the island to serve as the tail wagging global super dogs. ${ }^{2}$ Located on the edge of the East Asian continental shelf, the hegemonic United States views Taiwan as a crucial component of its Asian offshore defense. Resource-poor and industrially-efficient Japan perceives Taiwan, its former colony, decisive to its security and sea-borne trade. Simultaneously, Taiwan comprises a crucial part of China's national imagination. The island still considers itself officially as the Republic of China (ROC, or Taiwan), tracing its political lineage to the ROC established in the wake of the Chinese revolution in 1911. The resurgent People's Republic of China (PRC or China) treats the island as both a rival regime and a breakaway territory that has to be replaced and recovered. Beijing has never renounced the use of force to bring Taipei under its wing. In addition, both the PRC and Taiwan have made claims to islands in the East and South China Seas, which more or less clash with Japanese strategic and territorial aspirations. In the past, advocates of Taiwan's independence ${ }^{3}$ proposed abandonment of the ROC's claims over these disputed islands, reasoning that abandonment would improve their chances of gaining support from neighboring countries. This added to a Stratfor (a Texas-based thinktank) article forecasting that Taiwan might voluntarily give up its claims under an independence-leaning president after the 2016 election. ${ }^{4}$ Evidently, the party affiliation and the strategic policy alignment of the future ROC president are of crucial importance to all three powers, if not more. As such, plenty of ink has been spilt pondering the island's relations with China and its connection with East Asian peace and stability. Taiwan's sixth direct election, slated on January 16, 2016, like all others preceding it, has been carefully watched and analyzed by all sides.

The current cross-Strait relationship is generally described as, to use the terminology of Lund's Curve, unstable peace, ${ }^{5}$ not only because of third-party interests and involvement. Six decades of ideological, military and diplomatic conflict in the wake of the Chinese Civil War has transformed Taiwan into

2 M. McDevitt, Taiwan: The Tail That Wags Dogs, Asia Policy 2006, Number 1, pp. 69-93. Ch. Su, Taiwan's Relations With Mainland China: A Tail Wagging Two Dogs, London, Routledge, 2009.

3 Taiwan's independence, Taiwan independence, and secession are used interchangeably in the article to mean the same thing, even though the first two seem more positive and the latter less so.

4 Ending Taiwan's Broad South China Sea Claims, Stratfor, October 2, 2015.

5 Lund's Curve, a conceptual framework illustrating how a conflict tends to evolve over time, is an insightful tool for conflict analysis. According to Michael Lund, unstable peace refers to "a situation in which tension and suspicion among parties run high, but violence is either absent or only sporadic. A 'negative peace' prevails because although armed force is not deployed [or employed], the parties perceive one another as enemies and maintain deterrent military capabilities... but crisis and war are still possible." Michael Lund, Preventing Violent Conflicts: A Strategy for Preventive Diplomacy, Washington, D.C.: US Institute of Peace Press, 1996. 
a democratic society with little interest in unification ${ }^{6}$ with the PRC. Bi-partisan leaders in Taiwan, from Chiang Kai-shek to Chen Shui-bian, had relied on the U.S. and Japan for security and economic benefits. Yet, Chiang was devoted to a strand of Chinese nationalist identity (i.e., pro-China, but anti-communist) in sharp contrast to a Taiwanese identity held by Lee Teng-hui and Chen Shui-bian (i.e., both anti-China and anti-communist). Through revised textbooks and electoral mobilizations, Lee and Chen effectively transformed Taiwan's Chinese identities and sowed secessionist seeds into the minds of Taiwanese youth. They set on course a momentum of separatist movements under the proverbial iceberg of Taiwanese society. Candidate from a pro-independence party and protégé of the pro-Japanese, anti-China Lee Tenghui, Tsai Ing-wen just won the 2016 presidential election with a majority seats in the legislature. With a freer hand, Tsai could push for formal separation despite her pledge of maintaining the status quo. In Beijing's perspective, any attempts aiming at separating the self-governing island from China would be met with force, because the two sides are technically locked in the never-concluded civil war stage. ${ }^{7}$ The struggle over identity and Taiwan's future could inject new uncertainty in the convoluted relationship and renders only "negative peace" across the Taiwan Strait. ${ }^{8}$

This paper discusses a unique two-host framework in Taiwan's secessionist movement, nonexistent in other similar movements. With reviews of Taiwan's colonial experience under Japanese rule, it traces President Ma Ying-jeou's approach to cross-Strait relations, explaining reasons that led to Ma's unprecedented summit with his counterpart Xi Jinping, despite rising distrust of Ma in Taiwan. Without understanding the concept of the two hosts, it would be impossible to make sense of the extraordinary reconciliation, epitomized in the Xi-Ma handshake. The paper concludes that Beijing, the second host state whose aim is status quo, is unlikely to dramatically change its cross-Strait policy without political provocations from Taiwan.

\section{THE SECESSIONIST MOVEMENT AND ITS TWO HOSTS}

Typically, secession is a process of withdrawal of both territory and its population from an existing state (aka host state) and the creation of a new state (seceded state) on that territory. Justifications of secession often involve a nationalist ideology and experiences of a unique group. Such a process has four elements: a defined territory, a fixed population, proclamation of independence, and inter-

${ }^{6}$ Unification and reunification are used interchangeably in this text, meaning a willingness to be subjected to Beijing's rule whether under the "one country two systems" style or any other mutually agreed format.

7 The last time the two traded shots was in late 1970s. A peace treaty has yet been signed.

8 See Footnote 4 on Lund's Curve for details. 
national recognition. Official withdrawal requires a proclamation of independence and the ceasing to function of existing political and legal institutions of the host state. Previous name labels of the host state and its institutions, including the coats of arms and flags, are replaced with new ones. Gaining international recognition is the last step in the creation of a new state. To achieve the much coveted independence, the secessionist movement and the new political authority needs to have its independence recognized by other states and international organizations. Clearly, the proclamation is the defining mark of a secession; without such a proclamation, the secessionist movement can best be described as "attempts at secession." As a rule, secessionists tend to face one host. Case points are Catalonia versus Madrid, or the Confederate States versus the United States of America.

The ultimate goal of Taiwan's secessionists is to establish a Republic of Taiwan (ROT) to sever its umbilical cord with Mainland China. Unlike many separatist movements in Europe or elsewhere, Taiwan's secessionists face two hosts: The Republic of China (ROC) in Taipei embodied by the KMT and the People's Republic of China (PRC) in Beijing, both claiming to represent the whole of China that includes Taiwan. Secession from the ROC could be achieved fairly easily, via proclamation and justified by democracy. Secession from the PRC is more complicated because the latter has vowed to prevent it by all means. In the event of violence from the PRC, secessionists expect the United States and Japan to come to their rescue, which adds to the existing complexity in cross-Strait relations.

Without understanding the concept of the two hosts, it would be impossible to make sense of the unprecedented reconciliation under Kuomintang (KMT, or the Nationalists Party) leadership in the midst of rising anti-China sentiment in the island. It is fairly easy to understand the PRC's sentiment regarding Taiwan. As captured by Henry Kissinger, "Taiwan was where the dismemberment of China started - the first province to be annexed by colonialists... [and] its unification with the mainland is considered ... a 'sacred national obligation' which can be deferred for practical or tactical reasons but never abandoned." ${ }^{10}$ Taiwan certainly occupies the centerpiece of China's military modernization since Beijing's humiliation with Clinton's aircraft carriers. In March 2005 Beijing passed the Anti-Secession Law, Article 2 of which specifies Beijing's principle and resolve that "the state [PRC] shall never allow the 'Taiwan independence' secessionist forces to make Taiwan secede from China under any name or by any means." Article 8 states that a war could be triggered when any of the three conditions is met. First, "the fact" of Taiwan independence was achieved under whatever name or method. This could include the dropping of Taiwan's current political symbols - like transforming the official title from the ROC to ROT, changing its flags, redefining the ROC terri-

9 A. Pavkovic and Peter Radan, Creating New States: Theory and Practice of Secession Burlington, VT, Ashgate Publishing, Ltd. 2007, p. 33-37.

10 H. Kissinger, Does America Need a Foreign Policy?: Toward a Diplomacy for the $21^{\text {st }}$ Century, New York, Simon \& Schuster 2001, p. 150. 
tory to exclude the Mainland - and rewriting the Constitution of 1947. Second, "major incidents" transpired to force Taiwan's separation from the Mainland. Such incidents could include a unification-vs-independence referendum leading to secession, foreign invasion, a military coup, large scale riots, a military attack by Taiwan against the Mainland, or Taiwan's possession of weapons of mass destruction (WMD). The final condition that would warrant a Beijing intervention includes that all "possibilities" for reunification have been "completely exhausted." Though vague, it leaves open speculations that Beijing might compel reunification on Taiwan should it deem necessary. ${ }^{11}$ In Beijing's views, Taiwan's future is only one - eventual unification. Current de facto independence could be tolerated so long as the future is guaranteed. The One China principle thus serves as framing the relations toward this direction.

While Beijing's intention is easy to detect, Taipei's objectives are more confusing depending on which party is in office. The KMT traces its political lineage to the ROC founded in 1912 on the Mainland. At the time, Taiwan was still under Japanese colonial rule as a result of the Shimonoseki Treaty of 1895. In 1945 following Japan's defeat, the ROC declared Taiwan a province of the Republic, four years before its exile to Taiwan in the wake of its defeat in a bitter Civil War. Since then, the ROC's effective jurisdiction has been confined to Taiwan, Penghu, Kinmen [Jinmen] and Matsu [Mazu], the latter off-shore islands of the Mainland. Nonetheless, the ROC still claimed to be the legitimate government of the whole China. Consequently, the ROC and the PRC engaged in a nasty legitimacy contest, whereby every capital in the world became their diplomatic battlefield. Beijing asked every government it dealt with to endorse its version of the One China principle, as did Taiwan until early 1990s. In the 1970s when the United States and Japan negotiated diplomatic relations with Beijing, the two sides shared the same principle of One China including Taiwan. Henry Kissinger, the U.S. Secretary of State who had participated in the initial negotiations with both Taipei and Beijing, revealed that they were invariably concerned about Taiwan's secessionists, and that Nixon promised to Beijing that "the United States would not support internal Taiwan independence movements."

Curiously, weeks after Beijing's adoption of the Anti-Secession Law, reconciliation was achieved between the Chinese Communist Party (CCP) and the KMT, then in opposition. Retaining their historical name as the Chinese Nationalists, the KMT views itself not only as the ROC's primary political party, but synonymously the ROC state. It guards defensively any attempts that could diminish its legacy and has resisted calling for transforming itself into a Taiwan KMT. Under the independence-minded Democratic Progressive Party (DPP) and its former President Chen Shui-bian, Taiwan kept pushing the envelope regarding

${ }^{11}$ Full text of the Anti-Secession Law can be found http://www.china.org.cn/china/LegislationsForm2001-2010/2011-02/11/content_21898679.htm.

${ }^{12}$ H. Kissinger, On China, New York, The Penguin Press, 2011, p. 271. 
purging names in government and businesses that could suggest connections with China. In a common cause with resisting Chen's moves, KMT honorary chairman Lien Chan was well received in Beijing. In the midst of the 2004 electoral disputes and struggles over Taiwan's identity, Lien proposed to "beat swords into plowshares" with the Mainland based on a vague commitment of one-China with respective interpretations. In a statement expressing their historic ties, Lien found China's major infrastructure projects such as the Tibetan Railroad "having realized [KMT's founding father] Sun Yat-sen's vision."'13 Thus the two estranged parties formed a somewhat united front against secession, which paved ways for Ma's substantial reconciliation in his eight year term.

\section{IDENTITY RECONSTRUCTION, SECESSION, AND DEMOCRACY}

Back on the island, the two antagonistic groups - the KMT and then ruling DPP - engaged in identity politics. What they relished was not democracy but political power, as rightly pointed out by Yunhan Chu, scholar with Taiwan's Academia Sinica:

In the end, the state became the arena. The competing forces strove to gain control of the governing apparatus and use its power to steer cross-strait relations, erect a distinct cultural hegemony, and impose their own vision of nation-building, either in the direction of Taiwanization or Sinicization. ${ }^{14}$

To be fair, the seeds for identity discord were sowed not by either of the groups, but by tragic history. A part of China since the $17^{\text {th }}$ century, Taiwan was annexed by Japan in 1895 . For five decades, it was subjected to a sophisticated colonial rule, and the colonizers molded it into two distinct groups. The privileged landowning class was allowed to retain their land, and their children provided advanced education in Japan. The poor majority, on the other hand, was exposed to intense brutality and strove to protect traditional Han Chinese culture. During the last decade of Japanese rule, Japanization was introduced as a necessity of war; the use of Chinese language was banned; many were sent to China and Southeast Asia to fight for imperial Japan. The result was that the educated elite Taiwanese adopted the Japanese language, embraced its culture and aspired to be Japanese (i.e., Lee Teng-hui) while the underclass majority maintained their Han Chinese-ness having not forgotten their language and culture. Sandwiched

${ }^{13}$ Ch.N. Wei, Analyzing Taiwan Strait Relationships 2002-2007: A Four-Level Nested Games Approach, dissertation, UMI, 2008, p. 216-218.

${ }^{14} \mathrm{Chu}$, Yunhan, Taiwan's national identity politics and the prospect of cross-strait relations, Asian Survey 2004, July-August, pp.498-499. 
between the twin pressure of Japanese and Chinese modernity, this unique experience created a mixture of identity, which was neither Chinese nor Japanese. ${ }^{15}$

Yet that nuance was completely lost to the war-torn Chinese state under the KMT. When Chiang Kai-shek sent his soldiers to crack down on the rebellious natives on February 28, 1947, barely any effort was spared to understand the unique background of the new citizens. The massacre led to tens of thousands deaths, most of them elites and privileged. The subsequent land reforms, while mild compared with those launched by the Communists on the Mainland, were nonetheless at the expense of the landowning class. The mass migration of refugees from the Mainland as a result of the Chinese Civil War further strained the relationship between migrants and the native Taiwanese. ${ }^{16}$ In addition to Chinese gold reserve, cultural treasures, and entrepreneurs who loathed communism, the Chiangs brought with them the Mandarin language to replace both the local Minnan dialect and Japanese. Furthermore, they imposed an anti-Communist but China-centric world view in Taiwan's education system. They emphasized that Taiwan, or the "Free China," represented the last bastion of true Chinese culture, while their communist rivals on the Mainland were simply "bandits." With American aid, market support, and military protection, Taiwan grew to be one of the four Asian tigers in the 1980s. While the KMT monopolized political power, local Taiwanese excelled at business, medicine and law.

Affluence increases confidence; oppression breeds resistance; democratization opens new frontier of contention. Confluence of all three factors brought about open suspicion of the KMT as an occupant of the island instead of its legitimate ruler. Rise of the independence movement, especially street politics during the 1980s and 1990s further put the KMT government in a negative limelight, which led to fracturing of the party. To construct a unique Taiwanese identity, President Lee endorsed a policy in 1997 to correct the "pro-China-bias" in Taiwan's textbooks. The policy has since gained the name Concentric Circles View of History (tongxiyuan shiguan), which set Taiwan's instead of China's history in the center of the circles, followed by Chinese and then world history. ${ }^{17}$ Critics of this educational policy called the move a whitewashing of history. They derided the illogical move to transform the notorious "Comfort women" from "forced" sex slaves to "voluntary participants" as historical revisionism to "beautify" Japanese aggression. Critics further could not accept the change of Sun Yat-sen from his role as ROC founder to merely an alien from China. They criticized the controversial changes of Zheng Chenggong, (a.k.a. Koxinga) era to the non-existent

${ }^{15}$ P. Liao and D. Der-wei Wang (ed.), Taiwan Under Japanese Colonial Rule, 1895-1945: History, Culture, Memory, Columbia University Press, New York 2006; K.C. Lee, Taiwan zhengzhi fazhan shi [History of Political Development in Taiwan], Taipei, Youshi, 2013, p. 9-34.

${ }^{16}$ Lee, Taiwan zhengzhi fazhan shi, p. 35-94.

${ }^{17}$ F. Zhang, Taidu lishi jiaokeshu shi zenyang liancheng de? [How secessionist Taiwan history textbooks were manufactured], Guanchazhe [The Observers], 12 February, 2012 http://www. guancha.cn/ZhangFangYuan/2014_02_12_205199.shtml. 
"Zheng Dynasty" in Taiwan. In their views, this era should be correctly called the "Ming Zheng" period to emphasize its connection with China's Ming dynasty. ${ }^{18}$ Importantly, President Ma Ying-jeou of the KMT subscribes to the critics' view on the textbook issues.

\section{UNPRECEDENTED BREAKTHROUGH}

Since he came to office in a 2008 election, Ma promoted a balanced strategy in dealing with the three external powers. His approach has been simplified into six Chinese characters "qinmei, hezhong, youri" (literally, cozy to the U.S., peaceful with Mainland China, and friendly with Japan), designed to maximize Taiwan's geopolitical and geo-economic interests. ${ }^{19}$ With Mainland China, Ma adopted a "three no's" policy - no unification, no independence and no military confrontation - and largely maintained amicable relations with Beijing. Internationally, Ma espoused the viable diplomacy (huolu waijiao) and effectively ended the six-decade diplomatic competition with the PRC for recognition. Ma has been a key driver in forging closer ties with Beijing.

Ma won twice on the platform of the 1992 Consensus - "One China with respective interpretations" - representing a mandate from the people on the principle. As stated, Beijing supports the concept because of its implied anti-independence, upon which cross-Strait negotiations have been based. With Beijing's cooperation, direct trade and transportation links were established under Ma's watch. Negotiations have produced 23 agreements, including the signature Economic Cooperation Framework Agreement (ECFA) of 2010, notably East Asia's first free-trade accord which lowers tariffs and relaxes market access for 539 products and services for Taiwan. ${ }^{20}$ Considerable trade and tourism have linked the two sides. A few statistics illustrate this. In 2007, Taiwan had only 800 students and 20,000 tourists from the Mainland. In 2012, the number reached to 20,000 students and 2.5 million tourists. By 2015, these numbers had further risen to 40,000 Chinese students studied across the Straits with a concomitant increase of Chinese tourists to 4 million. Every week some 890 flights now fly between Taiwan and the Mainland, as compared to zero direct flights under Ma's predecessor. ${ }^{21}$ The Mainland has been Taiwan's biggest trading partner for more than a decade. Each

${ }^{18}$ Author's interview in Taiwan, March 2015.

${ }^{19}$ Fusheng Zeng, "zhonghua minguo fazhan zhanlue hexin siwei" [The core of the strategic thinking on Republic of China's development], National Policy Foundation, May 27, 2011, http:// www.npf.org.tw/3/9236.

${ }^{20}$ For a detailed discussion of the agreements, see Chunjuan Nancy Wei, Cross-Strait Relations Today: Challenges and Opportunities, in: Zhiqun Zhu, ed., New Dynamics in East Asian: Politics, Security, Political Economy, and Society, New York, The Continuum International 2012, pp. 83-101.

${ }^{21}$ ROC Year book, various years. 
year bilateral trade now exceeds $\$ 170$ billion; Taiwan benefits from a $\$ 100$-billion trade surplus with the mainland. Beijing's recent announcement of a permit-free entry policy for Taiwanese residents (without Taiwan's reciprocity), which commenced July 1, 2015, no doubt promotes closer people-to-people exchanges across the Strait. It has become Beijing's latest move to bring Taiwan closer.

Cross-Strait political relations have been institutionalized to a level. Since President Ma's tenure, Taipei and Beijing followed a "diplomatic truce," an implied agreement that neither government would seek to undermine the other's diplomatic allies using monetary inducement or other resources. Before 2014, negotiations were conducted by semi-official representatives, through the socalled "white gloves"; however, by February of that year, the first face-to-face meeting between official representatives occurred. The first ruling party leaders' summit - between sitting party chiefs Xi Jinping of the CCP and Eric Chu of the KMT - materialized in May 2015. Finally, only six months later in early November 2015, the cross-Strait summit of two presidents, though they addressed each other Mister instead of President, was realized in Singapore.

These achievements were made simultaneously with improved relations with Washington and Tokyo. For example, Taiwan became the 37th participant in the US Visa Waiver Program, as the only "country" in the program with which the US does not hold diplomatic ties. ${ }^{22}$ In 2012, Taiwan ranked as the 11th-largest U.S. trading partner. Taiwan signed a Fisheries Agreement with Japan over fishing rights in the East China Sea, based on Ma's East China Sea Peace Initiative, whose essence reads "sovereignty cannot be divided, but natural resources can be shared." While Ma strove to achieve a transparent relationship with all three major powers, his unexpected meeting with Chinese President Xi Jinping surprised all.

\section{THE XI-MA SUMMIT}

First of all, the land-mark encounter was unusually creative; some even liken it to Nixon's opening to China. No one had anticipated the two leaders to meet just seven months before Ma's stepping down. According to Ma, the goal of his trip was to simply consolidate cross-strait peace and maintain the status quo. ${ }^{23} \mathrm{In}$ reality, they met on the mutual agreed "1992 Consensus," reached in Singapore, which centers on the "One China with respective interpretations." Beijing desires "One China" while the KMT prefers "respective interpretations"; however, the DPP wants no part of it. The summit in a foreign country itself suggested that

${ }^{22}$ Taiwan's unique status on the list prompts the US Customs and Border Protection to include a footnote detailing the legal justification of making Taiwan a "country" in the United States. For details, see https://help.cbp.gov/app/answers/detail/a_id/1550/ /visa-waiver-program-(vwp)-countries.

${ }^{23}$ M. Ying-Jeou, When I said 'Mr. Xi', USA Today 2015, November 22, http://www.usatoday.com/story/opinion/2015/11/22/taiwan-china-xi-jinping-ma-ying-jeou-1992-consensus-column/76215872/. 
both leaders were aware that China is still a divided country composed of two regions - the Mainland Region represented by "Mr. Xi" and the Taiwan Region by "Mr. Ma." It constituted a de facto recognition, or a mutual non-denial, of the existence of a legitimate government in Taiwan and the Mainland respectively.

Second, the encounter was warm and cordial. The body language was telling: both men smiled broadly, and Xi extended his hand first. Compared with Xi's awkward handshake with Japanese PM Shinzo Abe earlier in 2015, the handshake in Singapore, lasting 81 seconds, conveyed a much different relationship: both leaders were genuinely happy with each other. In their closed door meeting, $\mathrm{Ma}$ proposed a hot line across the straits, which Xi readily accepted. Xi welcomed Taiwan's future membership in the Mainland-dominated Asian Infrastructure Investment Bank (AIIB). Ma expressed his desire to increase Taiwan's international space, and $\mathrm{Xi}$ agreed to review this on a case by case basis. Perhaps the most important achievement Ma made was to build a bridge for future leaders to meet. Small wonder that both leaders cited the meeting as one of their most important achievements in their $2016 \mathrm{New}$-Year Address.

Third, the two leaders, to avoid the contentious Westphalian system of sovereignty, operated on equality and respect, with Chinese characteristics. They appreciated respective political sensitivities, each "head of state" addressing the other with the ambiguous "Mister" instead of "President," setting aside the thorny sovereignty issues. Their color of ties $-\mathrm{Xi}$ in red while Ma in blue, which reflected the color of their respective parties - conveyed loyalty to party lines. They held hands against a backdrop of yellow, a color of Chinese emperors. Xi's name was printed in simplified Chinese, while Ma's in traditional Chinese. The dinner was arranged at a round table to avoid the political sensitivity of which side played the host. Each president was accompanied by six cabinet members with similar official functions and they split the bill. Xi served China's own Maotai wine, while Ma brought his carefully-chosen Kinmen Sorghum counterpart. Purchased in 1990, it reminded them of their nations' first contact in Kinmen when the unprecedented agreement was signed on jointly fighting crimes.

Fourth, Beijing, mindful that nothing substantial would come out of the meeting, resorted to emotional appeal. Xi's sentimental remarks summarized how Mainland Chinese viewed cross-Strait relationship: "No force can pull us apart because we are brothers connected by flesh even if our bones are broken. We are a family whose blood is thicker than water." As if it was not enough to express his resolve against secession, $\mathrm{Xi}$ continued, that the six decades of relations indicate that "no matter what kind of winds and rains are experienced by compatriots on the two sides, no matter how long divisions last, there is no power that can separate us." ${ }^{24}$ This meeting was further evidence of an increasing willingness of Beijing to live with the status quo across the Taiwan Strait so long as Taiwan does not

${ }^{24}$ Xi shakes hands with Ma at historic meeting, Sino-US.com, November 7, 2015, http:// www.sino-us.com/446/20490292018.html. 
pursue de jure independence. In addition, Xi's China Dream and his catchphrase "the great rejuvenation of the Chinese state" seemed endorsed by Ma.

Five, the meeting was more a reward to $\mathrm{Ma}$, who had expressed hopes for a cross-Strait summit in public for at least three years prior to the event. Having no pressure for reelection, Ma had the liberty to pursue his personal legacy as a Chinese nationalist. Raised in a family supporting Chinese reunification, Ma revealed in 2010 that his real name 膺九 instead of the commonly known 英 九 actually meant "embracing China." 25 Ma's late father, a staunch supporter of the traditional KMT vision of a unified China, not only gave him the pro-China name; he also left a will corresponding to Xi's China Dream. The will seems an instruction to his beloved son, who was not the ROC president at the time, the key phrases scribed on his urn make a couplet that reads: "defusing independence [in Taiwan] and gradually pushing for reunification so that China can be revitalized in all fronts; assisting the strong [the U.S. and Europe] and supporting the weak so that the world could move towards [the Confucian ideal of] great unity" (huadu jiantong quanmian zhenxing zhongguo; fuqiang xieruo, yiqi maixiang datong). ${ }^{26}$ Yet this view of an eventual reunification with the Mainland is increasingly unpopular among the youth of Taiwan, which prompted a columnist at the Hong Kong-based Phoenix's Weekly to refer to Ma as "the last Chinese in Taiwan."27 With only seven months left in office, one could see that Ma was more eager for the meeting than Xi was. Yet, at a time when Ma's KMT was widely expected to lose the presidential and legislative elections in January 2016, the summit seemed to be more of a prize for him: Ma fulfilled his desire for historical legacy, cementing his personal mark on cross-Strait relations.

Sixth, the encounter created a new threshold of status quo, which the DPP and its Chairperson Tsai Ing-wen could be difficult to break away from. When the news of the summit broke, Tsai's immediate response was being "ambushed." As mentioned earlier, Tsai does not want any portion of the 1992 Consensus. To her chagrin, the summit further elevated the status of the 1992 Consensus, a principle $\mathrm{Xi}$ has likened to a solid foundation without which cross-Strait relations could be precarious as "ground shaking and mountains swaying." Although it has put Taipei in an equal footing with Beijing and helped maintain unprecedented peace, the opposition leader wants to keep all options open for Taiwan and refuses to commit to the 1992 Consensus. Indeed, the summit may have resulted in limiting the wiggle room of the DPP.

Seventh and final, the summit brought freedom for three previously captured intelligence agents. Weeks after the summit, officials on both sides confirmed an

${ }^{25}$ President Ma revealed his real name and its meaning in a 2010 visit with then 90 -year-old poet Zhou Mengdie.

${ }^{26}$ The full text of Ma Heling's will in Chinese can be found http://www.360doc.com/content/08/0725/10/42905_1467113.shtml.

${ }^{27}$ M. Jun, Taiwan zouru zuihou de zhongguoren shidai [Taiwan Walks into 'The Last Chinese' Era], Financial Times Chinese, June 25, 2015, http://big5.ftchinese.com/story/001062693?full=y. 
extraordinary spy swap occurred prior to the meeting: China first released two colonels in mid-October in return for Taiwan's release later that month of a double agent who was accused of spying for Beijing. All three men had been sentenced to life terms before advance parole leading to their release. The pair working for Taiwan's Military Intelligence Bureau (MIB) was captured along the Sino-Vietnamese border in May 2006 and had been held for more than nine years before freedom. The third spy was arrested in Taipei in 1999 in the wake of the 1996 missile crisis. ${ }^{28}$ The unprecedented swap, although a baby step toward improving mutual trust, was nonetheless a significant move in their relations.

\section{CONCLUSION}

The Mainland and Taiwan share a profound interest in the continuation of cross-Strait peace and stability. An existing paradox in the current relations manifests in the rising anti-China sentiment in Taiwan's society amidst an unprecedented cross-Strait economic integration and cooperation. This paper seeks to explain the paradox and the unique two-host phenomenon that Taiwan's secessionists have to face.

Ma's China-friendly initiatives have become unpopular with many Taiwanese voters, who think his efforts undermine the island's possibility of de jure independence, or eventual secession, and hurt its economy. As a loyal KMT member who does not favor unification, Ma is opposed to independence, while his successor is likely an independence-leaning DPP Chairperson. Despite a long history supporting secession, Ms. Tsai Ing-wen has proclaimed to maintain cross-Strait status quo, but she chose to reject the only working formula - the 1992 Consensus - to achieve the status quo. Facing uncertainty, the ROC/KMT and the PRC, as two hosts resisting secession, have inched closer, culminating in the unprecedented summit in Singapore.

As with past Taiwanese presidential elections, the 2016 vote was closely watched and interpreted by the U.S., Japan and Mainland China because of its international and regional implications. The real import of the unprecedented XiMa meeting can be measured only after her inauguration in May. With Beijing's insistence on identifying the 1992 Consensus as precondition to a stable relationship, it is expected that her wiggle room will be constrained. Both Ma and Xi, representatives of the twin hosts against Taiwan's independence, have worked to put a leash on secession. But the DPP's solid victory with majority in the legislature has provided a strong mandate for the DPP to pursue its agenda. In addition, the five seats won by the radical New Power Party, a result of the Sunflower

${ }^{28}$ Taiwan junfang zhengshi liang'an mimi jiaohuan beifu qingbao renyuan [Taiwan's military confirms the secret cross-Strait swap of captured intelligence agents], The Observers, November 30,2015, http://www.guancha.cn/local/2015_11_30_343030.shtml 
Movement, and a party formed less than one year, would further magnify forces wishing to make moves toward a more formal separatist status.

The 2016 presidential election again highlights the unstable nature of the cross-strait peace. Now that it has again entered on the election-driven cycle in which tension and suspicion among parties run high, it is time for high-level communication initiatives to be launched to stabilize ties across the Taiwan Strait, as so called for by Lund's Curve of Conflict. As Taiwan's security guarantor and China's chief economic partner, the United States can and is expected to play the most crucial role to stabilize the troubled Taiwan Strait. The two-host theory could be useful for theorizing future behaviors of a likely DPP-led Taiwan, and the responses of the opposition KMT and China's Xi.

\title{
PROBLEM SECESJI TAJWANU W DEBACIE POLITYCZNEJ NA SZCZYCIE XI-MA. IMPLIKACJE DLA STOSUNKÓW W CIEŚNINIE TAJWAŃSKIEJ
}

\begin{abstract}
Abstrakt. Tajwan przyciąga uwagę całego świata ze względu na znaczenie geopolityczne wyspy w regionie Azji i Pacyfiku. Demokratyzacji Tajwanu towarzyszą ruchy secesyjne, co stwarza dodatkowe komplikacje. Prowadzi to wzrostu zagrożeń w różnych obszarach, politycznym, militarnym, ekonomicznym. Pomimo, że stosunki w Cieśnienie Tajwańskiej można obecnie określić jako względnie spokojne, sytuacja nadal nosi znamiona „niestabilnego pokoju””, używając terminologii zaproponowanej przez Lund Curve. W sytuacji gdy nadrzędnym celem Chin pozostaje zjednoczenie narodowe, większość tajwańskich wyborców faworyzują zachowanie status quo. Tym bardziej na uwagę zasługuje analiza bezprecedensowego spotkania prezydenta Ma Ying-jeou (Tajwan) z Xi Jinping (Chiny), które miało miejsce w listopadzie 2015 roku. Było to pierwsze spotkania tej rangi urzędników od zakończenia wojny domowej czyli od $1949 \mathrm{r}$.
\end{abstract}

Słowa kluczowe: spotkanie Xi-Ma, niestabilny pokój, stosunki w Cieśninie Tajwańskiej, wybory prezydenckie na Tajwanie 2016 